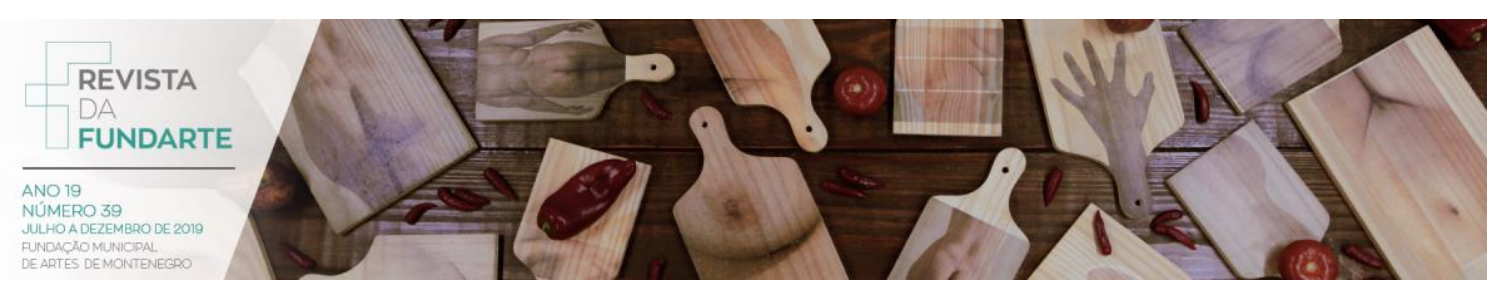

INVESTIGANDO SOBRE MÚSICA E ALFABETIZAÇÃO NA ESCOLA

Paloma Bastos Moreira Cristina Rolim Wolffenbüttel

MOREIRA, Paloma Bastos; WOLFFENBÜTTEL, Cristina Rolim. Investigando sobre música e alfabetização na escola. Revista da FUNDARTE. Montenegro, p. 24-47, ano 19, no 39 , julho/dezembro de 2019.

Disponível em: http://.seer.fundarte.rs.gov.br/index.php/RevistadaFundarte/index $>20$ de dezembro de 2019. 


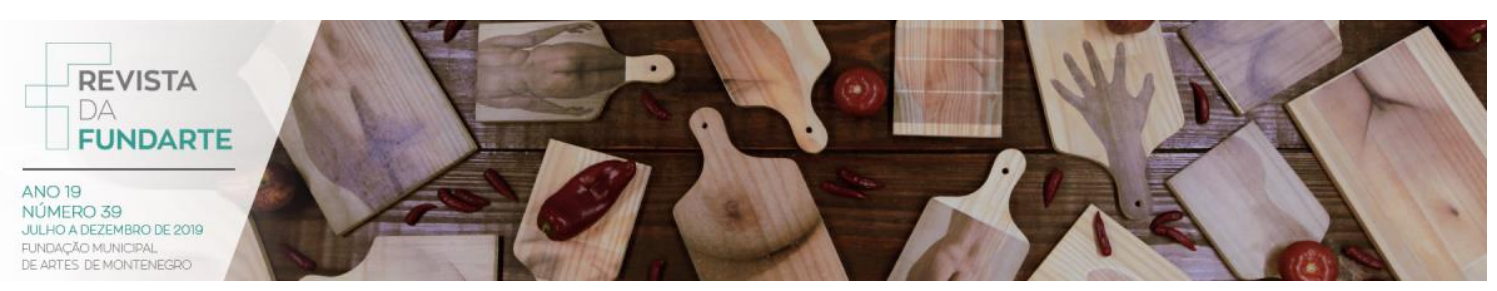

\title{
INVESTIGANDO SOBRE MÚSICA E ALFABETIZAÇÃO NA ESCOLA
}

\author{
Paloma Bastos Moreira ${ }^{1}$ \\ Cristina Rolim Wolffenbüttel${ }^{2}$
}

\begin{abstract}
Resumo: A investigação analisou a utilização da música na alfabetização escolar. A metodologia teve como base uma abordagem qualitativa, exploratória, descritiva e participante. As técnicas para a coleta dos dados incluíram questionários autoadministrados com professoras alfabetizadoras dos anos iniciais e a realização de observações de suas práticas. Também foram contatadas as coordenações pedagógicas das escolas como complemento às informações. Como resultados da pesquisa verificou-se que as professoras alfabetizadoras utilizam a música em sala de aula por meio de atividades pedagógico-musicais diversas, como interpretação das letras de canções e realização de atividades lúdicas. Constatou-se, também, que as professoras alfabetizadoras entendem que a música deve fazer parte do currículo escolar, apontando razões pedagógicas para essa presença. Por fim, considerando-se a constatação da necessidade de uma formação continuada em música por parte das professoras investigadas, oportunizou-se um curso de extensão de educação musical com vistas a contribuir com esta necessidade.
\end{abstract}

Palavras-chave: Educação; Educação Musical; Alfabetização.

\section{INVESTIGATING ABOUT MUSIC AND LITERACY AT SCHOOL}

Abstract: The research analyzed the use of music in school literacy. The methodology was based on a qualitative, exploratory, descriptive and participatory approach. Data collection techniques included self-administered questionnaires with literacy teachers from the initial years and observations of their

${ }_{1}^{1}$ Possui graduação em Pedagogia pela Universidade Estadual do Rio Grande do Sul (2017). , atuando principalmente no seguinte tema: jogos e brincadeiras. educação infantil. infância. educação musical. alfabetização.

2 Doutora e Mestre em Educação Musical pela Universidade Federal do Rio Grande do Sul; Especialista em Informática na Educação Ênfase em Instrumentação, pela Pontifícia Universidade Católica do Rio Grande do Sul. Licenciada em Música pela Universidade Federal do Rio Grande do Sul. Coordena o curso de Especialização em Educação Musical na Universidade Estadual do Rio Grande do Sul, Unidade de Montenegro. É coordenadora da Área Música do Programa de Iniciação à Docência, em Montenegro, da CAPES/UERGS. Coordena a Comissão de Pesquisa e Pós-Graduação da Uergs-Montenegro, orientando bolsistas de iniciação científica em música e artes, da FAPERGS, CNPq e UERGS. É coordenadora dos grupos de pesquisa registrados no CNPq Arte: criação, interdisciplinaridade e educação e Educação Musical: diferentes tempos e espaços. Coordena o Programa de Extensão Universitária, do Ministério da Educação, pela Uergs, na temática da ampliação da leitura através das Artes, desenvolvendo ações de leitura com estudantes bolsistas, beneficiando as redes públicas municipais e estaduais de Porto Alegre e Montenegro. Na Prefeitura de Porto Alegre, a partir da atuação na Secretaria Municipal de Educação, é assessora pedagógica e coordena os programas Centros de Dança e Brinca, propondo e desenvolvendo políticas públicas para a inserção das artes nas escolas da Rede Municipal de Ensino de Porto Alegre. Criou, em conjunto com colegas professores da rede municipal de Porto Alegre, o Programa Centros Musicais, uma proposta de política pública para o ensino de música na escola, em vigor na Secretaria Municipal de Educação do município, o qual coordena desde sua criação. É Diretora Científica da Coleção Educação Musical, da Editora Prismas, de Curitiba. Faz parte da Comissão Gaúcha de Folclore e da Fundação Santos Herrmann.

MOREIRA, Paloma Bastos; WOLFFENBÜTTEL, Cristina Rolim. Investigando sobre música e alfabetização na escola. Revista da FUNDARTE. Montenegro, p. 24-47, ano 19, ํo 39, julho/dezembro de 2019.

Disponível em: http://.seer.fundarte.rs.gov.br/index.php/RevistadaFundarte/index> 20 de dezembro de 2019. 


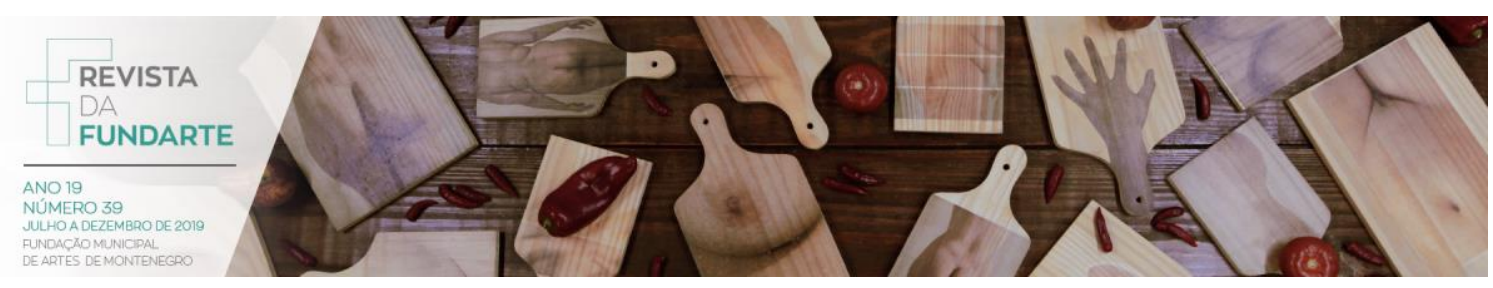

practices. The pedagogical coordinations of the schools were also contacted as a complement to the information. As a result of the research, it was verified that literacy teachers use music in the classroom through various pedagogical-musical activities, such as the interpretation of song lyrics and the performance of play activities. It was also verified that the literacy teachers understand that music should be part of the school curriculum, pointing out pedagogical reasons for this presence. Finally, considering the need for a continuous training in music by the teachers investigated, a course of extension of musical education was opportunized in order to contribute with this necessity.

Keywords: Education; Music Education; Literacy.

\section{Introdução}

O processo de aprendizagem musical tem início quando somos bebês e é espontâneo, pois desde o ventre materno já podem ser escutados sons e ritmos. A voz da mãe, o sangue que flui, o coração que pulsa, por meio destes fenômenos, são transmitidos sentimentos e sensações ao bebê. Já quando criança, as cantigas de ninar ganham seu espaço de aconchego e ajudam a desenvolver uma audição aguçada para a música, já que, aos poucos, quando aprendem a falar, as crianças cantam, dançam e brincam.

O educador pode aproveitar esse contato nato com a música desde cedo para utilizá-la como elemento de aprendizagem. A respeito do universo sonoro dos bebês, Brito (2003) explica que

começa ainda antes do nascimento, pois na fase intrauterina os bebês já convivem com um ambiente e de sons provocados pelo corpo da mãe, como o sangue que flui nas veias, a respiração e a movimentação dos intestinos. A voz também constitui material sonoro especial e referência afetiva para eles. (BRITO, 2003, p. 35).

Mesmo que em muitas escolas a música ainda seja utilizada como elemento de recreação em datas festivas e para momentos relaxantes, pode-se iniciar uma reflexão sobre o fato de que, se valorizada, a música pode ser bastante contributiva no campo pedagógico e, assim, ganhar um espaço significativo nas salas de aula.

Encorajar a criação de novas formas de expressão por meio da música vai além da realização de apresentações, por mais importantes e prazerosas que estas sejam; exige criatividade, paciência, e trabalho árduo. Além disso, os resultados

MOREIRA, Paloma Bastos; WOLFFENBÜTTEL, Cristina Rolim. Investigando sobre música e alfabetização na escola. Revista da FUNDARTE. Montenegro, p. 24-47, ano 19, no 39 , julho/dezembro de 2019.

Disponível em: http://.seer.fundarte.rs.gov.br/index.php/RevistadaFundarte/index $>20$ de dezembro de 2019. 


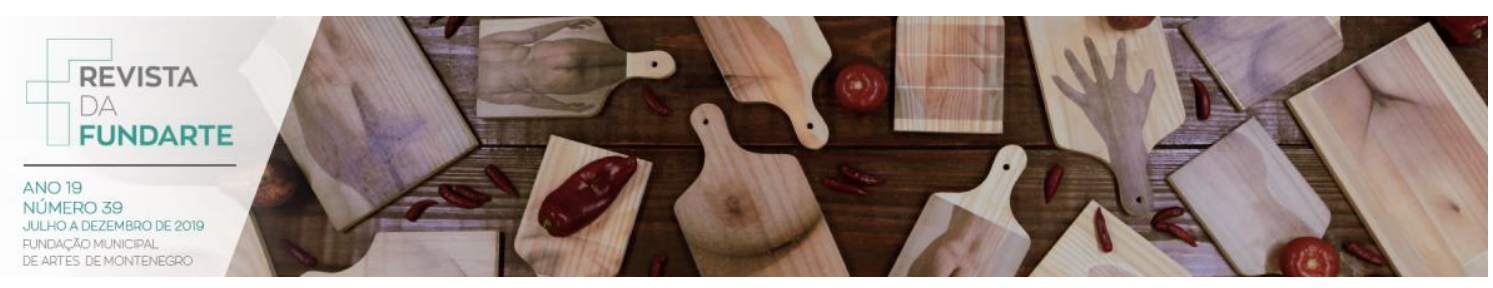

não são rápidos, ao contrário, da mesma forma que ensinamos a criança a falar, teremos a oportunidade trabalhar a linguagem musical, alfabetizando-as.

Scherer (2010) explica:

O que não está acompanhando a música nas salas de aula é a compreensão do papel da música na educação das crianças, da importância da musicalização no desenvolvimento dos alunos, da influência da música no processo de alfabetização das crianças nos anos iniciais. (SCHERER, 2010, p. 10).

A Lei no 11.769, de 19 de agosto de 2008 (BRASIL, 2008), que altera o artigo 26ํ da Lei de Diretrizes e Bases da Educação Nacional, dispôs sobre a obrigatoriedade do ensino de música nas escolas brasileiras. Como a Lei não prevê a obrigatoriedade da formação específica de professores para a realização deste trabalho, no caso de licenciados em música, e os cursos de Pedagogia não possuem habilitação específica para a realização deste ensino, a responsabilidade ainda tem ficado a cargo dos professores unidocentes para que a Educação Musical aconteça nas escolas, o que ocorre de forma interdisciplinar, envolvendo o ensino da música e os conteúdos programáticos curriculares, tornando a música a própria natureza didática das aulas para alfabetizar as crianças, e desenvolvendo uma visão de mundo. Concorda-se com Bellochio, Weber e Souza (2017), as quais argumentam que:

a Música é uma das áreas do conhecimento que compõe um conjunto de saberes e práticas importantes ao desenvolvimento dos seres humanos. Importante porque faz parte do dia a dia da vida dos estudantes. Importante, também, porque a música pode ser criada e inventada no contexto da educação básica. (BELLOCHIO; WEBER; SOUZA, 2017, p. 4).

O problema que tem sido enfrentado em todas as épocas é a formação e a capacitação docente. Para se lecionar ou ensinar música é necessário e indispensável a existência de um profissional da área. A proposta resultante muitas vezes, então, é relacionar música com a alfabetização, que engloba a área dos professores que estão na rede básica e que não possuem, necessariamente, formação em música.

MOREIRA, Paloma Bastos; WOLFFENBÜTTEL, Cristina Rolim. Investigando sobre música e alfabetização na escola. Revista da FUNDARTE. Montenegro, p. 24-47, ano 19, ํo 39, julho/dezembro de 2019.

Disponível em: http://.seer.fundarte.rs.gov.br/index.php/RevistadaFundarte/index $>20$ de dezembro de 2019. 


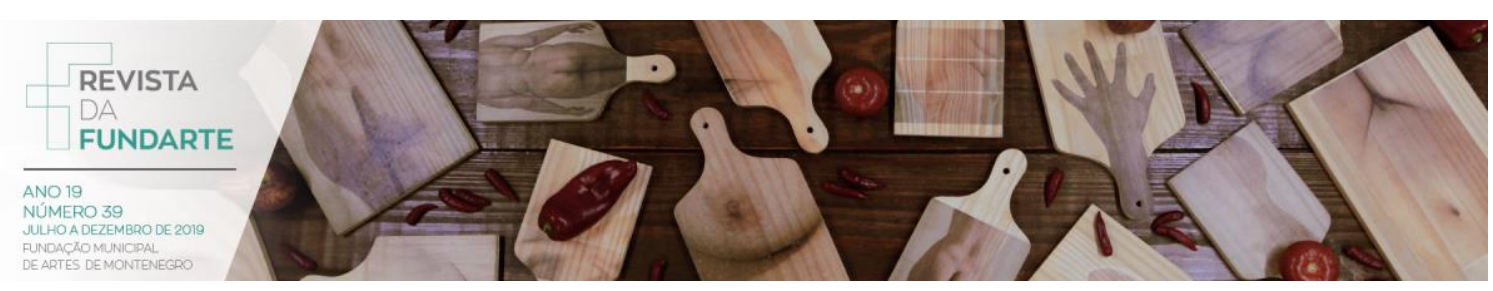

Para que a música entre em sala de aula de forma eficaz, entende-se a necessidade de um saber específico em relação à música, a fim de contemplar tudo o que esta Arte pode oferecer em questão de desenvolvimento humano.

O ensino na escola sendo interdisciplinar, dinâmico, lúdico, musical e utilizando o corpo para o conhecimento de si e do mundo, deveria ser tratado como uma prioridade escolar e colocado sistematicamente nos planejamentos didáticos, pois a maneira como os conteúdos são constituídos e a forma como os alunos aprendem são essenciais. A didática do trabalho é extremamente importante! De acordo com os Parâmetros Curriculares Nacionais (BRASIL, 1997a):

\begin{abstract}
Quando se pretende que o aluno construa conhecimento, a questão não é apenas qual informação deve ser oferecida, mas, principalmente, que tipo de tratamento deve ser dado à informação que se oferece. A questão é então de natureza didática. Nesse sentido, a intervenção pedagógica do professor tem valor decisivo no processo de aprendizagem e, por isso, é preciso avaliar sistematicamente se ela está adequada, se está contribuindo para as aprendizagens que se espera alcançar. (BRASIL, 1997a, p. 38, grifo nosso).
\end{abstract}

A questão, então, não é quais informações musicais, mas como os elementos musicais ou os conteúdos da música podem ser desenvolvidos. A natureza didática das aulas é de total autonomia dos professores e, sendo assim, a música pode ser utilizada para despertar, estimular e desenvolver o conhecimento, possibilitando que as crianças se tornem seres criativos e capazes de acreditar em si mesmos. A esse respeito, Fonterrada (1994) explica que:

o aprendizado da música envolve a constituição do sujeito musical, a partir da constituição da linguagem da música. O uso dessa linguagem irá transformar esse sujeito, tanto no que se refere a seus modos de perceber, suas formas de ação e pensamento, quanto em seus aspectos subjetivos. Em consequência, transformará também o mundo deste sujeito, que adquirirá novos sentidos e significados, modificando também a própria linguagem musical. (FONTERRADA, 1994, p. 41).

É importante lembrar que as atividades musicais e corporais não são aulas de desconcentração, mas esse conhecimento deve estar inserido no trabalho, e pode ser um princípio norteador para o ensino dos conteúdos específicos exigidos para a

MOREIRA, Paloma Bastos; WOLFFENBÜTTEL, Cristina Rolim. Investigando sobre música e alfabetização na escola. Revista da FUNDARTE. Montenegro, p. 24-47, ano 19, ํo 39, julho/dezembro de 2019.

Disponível em: http://.seer.fundarte.rs.gov.br/index.php/RevistadaFundarte/index $>20$ de dezembro de 2019. 


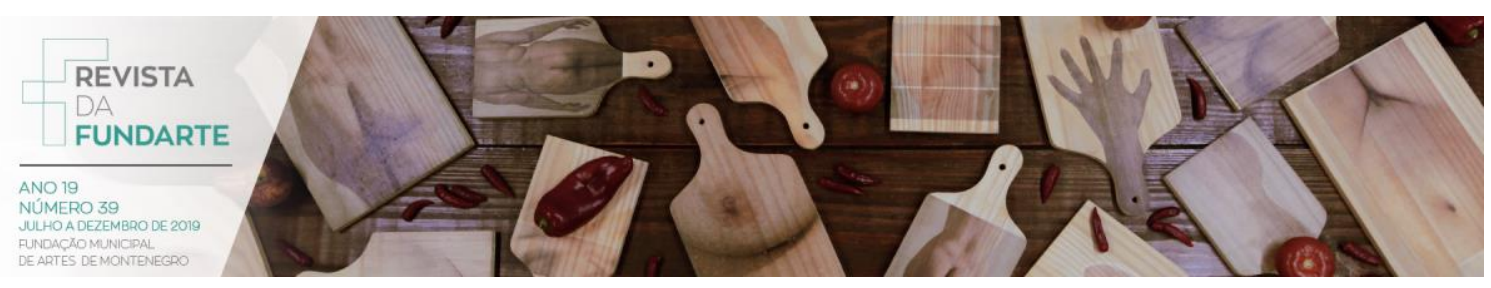

formação do aluno. A música não é apenas uma ferramenta que ajuda na alfabetização e no letramento, no ensino da matemática, das ciências ou nas demais áreas do conhecimento, como mencionado anteriormente, mas ela pode ser a própria natureza didática das aulas, partindo dela e dos conteúdos, os objetivos gerais e específicos, a metodologia, os recursos e a avaliação. Conforme sustenta Queiroz (2004, p. 3), a "música, por sua forte e determinante relação com a cultura, ocupa dentro de cada grupo humano um importante espaço com significados, valores, usos e funções que a particularizam de acordo com cada contexto sociocultural".

Por meio da didática musical pedagógica, os alunos podem adquirir a habilidade para conhecer a música, reconhecer na música a sua cidadania, a sua participação social e política, bem como os seus direitos e deveres. E obter a capacidade de análise crítica e de posicionamento, de maneira responsável na sociedade, valorizando a pluralidade cultural, questionando a realidade e expressando suas ideias, não deixando de lado o corpo, a valorização dos cuidados do seu próprio corpo e os hábitos saudáveis em busca de uma qualidade de vida melhor (BRASIL, 1997c, p. 69).

O conhecimento de algumas palavras que possam surgir no vocabulário de estudantes remete à cultura e ao local onde vivem, e as músicas sempre têm uma influência considerável. Esta prática ajuda a despertar o interesse e a magia em aprender a ler e a escrever, unindo o que as crianças vivenciam com relação à música em seu cotidiano ao que seria o adequado processo de alfabetização que vivenciará na escola por longo período. É um desafio para os professores que as crianças compreendam o sistema de signos e símbolos musicais, porém os sons e os fonemas podem facilitar esse processo quando se ouve e reconhece as palavras pela música. Jeandot (1990), nesse sentido, destaca:

A conduta do professor é essencial em todo o processo de aprendizagem. Embora seja mais cômodo impor silêncio, o educador deve esforçar-se para respeitar os ruídos que as crianças produzem na classe, bem como encontrar nessa massa sonora um embrião de expressão musical coletiva; ele deve ainda procura compreender o aluno que incansavelmente repete uma mesma formula rítmica. (JEANDOT, 1990, p. 132).

MOREIRA, Paloma Bastos; WOLFFENBÜTTEL, Cristina Rolim. Investigando sobre música e alfabetização na escola. Revista da FUNDARTE. Montenegro, p. 24-47, ano 19, ํㅡ 39 , julho/dezembro de 2019.

Disponível em: http://.seer.fundarte.rs.gov.br/index.php/RevistadaFundarte/index $>20$ de dezembro de 2019. 


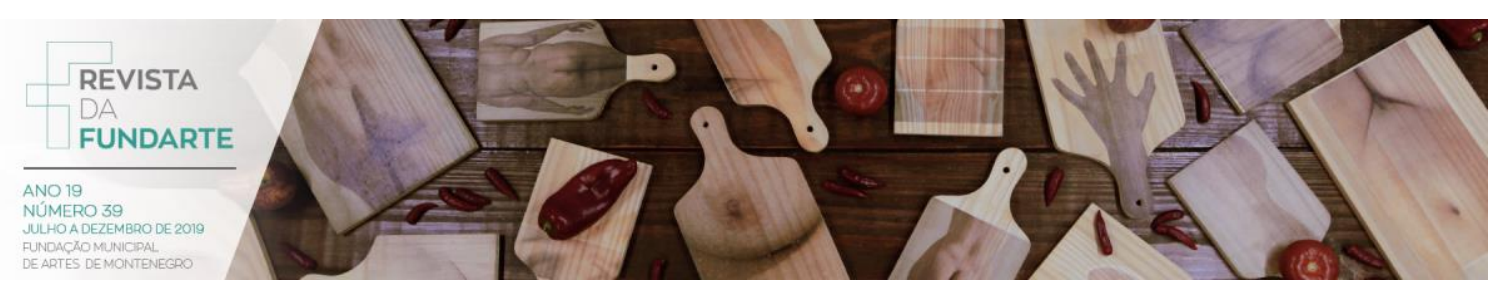

Quando se tem uma prática pautada pela escuta, é possível criar projetos musicais em que todos tenham participação, interesse em pesquisar e registrar, conseguindo englobar outras áreas de conhecimento e assuntos que são pouco abordados ou não escolhidos para estudo. Conforme postula Demo (1999), a participação é extremamente importante, encontra-se no âmago dos desejos políticos das pessoas; é a participação que sedimenta suas metas eternas de autogestão, de democracia, de liberdade e de convivência.

As pesquisas sobre professores não especialistas em música que reconhecem o valor que esta prática possui tornam-se um incentivo e podem auxiliar os educadores a ficarem mais seguros para incluir a música em sala em aula, já que não possuem formação para tal. Esta formação muito importante e necessária deveria ser uma proposta de discussões nas escolas, para que todos pudessem compreender o que é necessário para que essa formação aconteça e como ensinar música para as crianças, saber o que, para que e para quem ensinar é da mesma forma importante. Conforme Spavanello e Bellochio (2005),

um trabalho musical de qualidade, no espaço da escola, também passa pelo comprometimento com a educação, em sentido amplo. A proposta, tanto de formação de professores quanto de práticas educativas para o ensino de música na escola, deve ser tomada como uma conquista coletiva entre unidocentes e especialistas em música, de modo que estes profissionais compreendam que, se saber o conteúdo musical é necessário para ensinar música, saber o quê, para que e para quem ensinar é da mesma forma importante, dentro de uma perspectiva de educação consciente e comprometida com 0 desenvolvimento humano. (SPAVANELLO; BELLOCHIO, 2005, p. 93).

Segundo Kraemer (2000), é importante compreender que a pedagogia não se constitui como uma ciência isolada, mas ela se apresenta como um guarda-chuva ou um campo de trabalho para numerosas ciências isoladas de diferentes espécies para a solução de problemas pedagógicos.

MOREIRA, Paloma Bastos; WOLFFENBÜTTEL, Cristina Rolim. Investigando sobre música e alfabetização na escola. Revista da FUNDARTE. Montenegro, p. 24-47, ano 19, ํㅡ 39, julho/dezembro de 2019.

Disponível em: http://.seer.fundarte.rs.gov.br/index.php/RevistadaFundarte/index $>20$ de dezembro de 2019. 


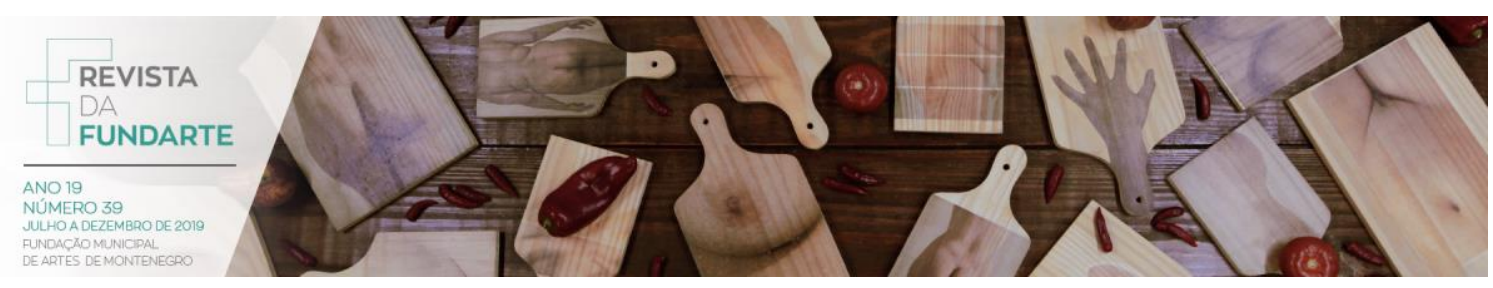

\section{O Canto Orfeônico e a Educação Musical}

Iniciando um novo período na educação brasileira, no ano de 1961, o Canto Orfeônico, sob a orientação de Heitor Villa-Lobos, foi substituído pela Educação Musical por meio da Lei de Diretrizes e Bases da Educação. Na publicação da LDB 4.024/61, fala-se, no artigo 38, parágrafo IV, sobre atividades complementares de iniciação artística (BRASIL, 1961); assim, tornando o ensino opcional nas escolas e deixando a música em segundo plano no currículo, já que as especializações necessárias também não eram desenvolvidas para tal. A Educação Musical, assim, veio a contrapor o Canto Orfeônico, mudando o enfoque.

$\mathrm{Na}$ década de 1970 a música foi retirada, como especificidade, dos currículos escolares, e os professores tiveram a necessidade de realizar um trabalho que comumente se começou a denominar como polivalente, tendo em vista que o trabalho apontado nos documentos legais incluía as Artes Plásticas, Desenho, Música, Artes Industriais e Artes Cênicas. Com isso se colocava de lado a formação especifica, sendo necessário que o professor dominasse todas essas áreas, resultando a diluição do trabalho musical, sem falar no trabalho nas demais áreas, também extremamente importantes para o desenvolvimento humano, intelectual, enfim, para o aprendizado de todas as pessoas em sua escolarização.

Nos anos 80 teve início o movimento Arte-Educação para que se conscientizassem os professores de artes, e que, através de discussões e do aprimoramento dos professores, cada um assumisse seu papel e suas especificidades na educação em artes (BRASIL, 1997c). Com a nova Lei de Diretrizes e Bases da Educação Nacional nำ 9.394 de 1996, Art. 26ํㅗ $§ 2^{\circ}$, o ensino da arte se tornou componente curricular obrigatório nos diversos níveis da educação básica, de forma a promover o desenvolvimento cultural dos alunos (BRASIL, 1996). Assim, nos anos 90, aconteceu uma mobilização para novas tendências e, principalmente, se modificou o nome do componente Educação Artística para Artes (BRASIL, 1997c).

MOREIRA, Paloma Bastos; WOLFFENBÜTTEL, Cristina Rolim. Investigando sobre música e alfabetização na escola. Revista da FUNDARTE. Montenegro, p. 24-47, ano 19, ํㅡ 39, julho/dezembro de 2019.

Disponível em: http://.seer.fundarte.rs.gov.br/index.php/RevistadaFundarte/index $>20$ de dezembro de 2019. 


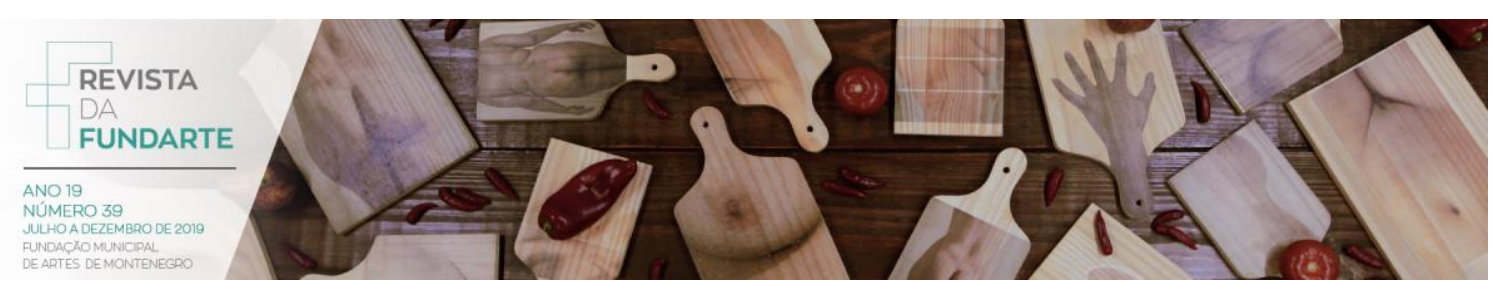

Em 2008, a música conquistou, novamente, seu espaço como campo de conhecimento na escola, por meio da Lei no 11.789 (BRASIL, 2008), sendo vetado o artigo em que era exigido um profissional da área para tal. Sendo assim, a responsabilidade permaneceu nos professores da Educação Básica que atuam na escola, mas em outras áreas do conhecimento. Assim, a efetiva inserção do ensino de música nas escolas ficou prejudicada, considerando-se a falta de formação específica em música por parte dos professores.

O Conselho Nacional de Educação (CNE), em 2013, em parceria com a Associação Brasileira de Educação Musical (ABEM), por meio de audiências públicas, discutiu o assunto que resultou no Parecer CNE/CEB nำ12/2013, definido através da Resolução $\mathrm{n}^{\circ}$ 2, de 10 de maio de 2016, o que trouxe como finalidade ajudar na implementação da Lei no 11.769/2008, o que resultou em concursos públicos para professores de música no estado do Rio Grande do Sul (WOLFFENBÜTTEL; ERTEL; SOUZA, 2016).

Porém, leis, pareceres e resoluções não são suficientes para garantir a efetiva inserção da música nas escolas. Desse modo, é importante refletir sobre a formação dos professores unidocentes, posto que, muitas vezes, são eles que acabam desenvolvendo atividades musicais nas escolas. Além disso, reconhecemse os limites de atuação desses professores, uma vez que é a Licenciatura em Música que efetivamente habilita para o trabalho pedagógico-musical. Todavia, se não há um suporte maior na formação de professores unidocentes, como fazer?

A respeito dos profissionais indicados para a docência em música nas escolas, Fonterrada (1998) convida à reflexão. A autora questiona e analisa:

quem deve dar aulas de música? O professor de classe? O professor de Artes? O músico que é também professor de Educação Musical? Sem dúvida, há muitas atividades que o professor não músico pode desenvolver com sua classe para estimular o gosto pela música; sem dúvida, é possível cantar ou tocar, mesmo que o professor não saiba ler música; sem dúvida, ele poderá conduzir o interesse da classe na apreciação do ambiente sonoro escolar ou das imediações. Para isso, ele não necessita de formação específica, mas apenas de musicalidade e interesse pela música e pelos sons. Mas, mesmo para isso, é necessário que tenha uma só- lida orientação. [...] Outras questões, porém, são da alçada do professor

MOREIRA, Paloma Bastos; WOLFFENBÜTTEL, Cristina Rolim. Investigando sobre música e alfabetização na escola. Revista da FUNDARTE. Montenegro, p. 24-47, ano 19, ํo 39, julho/dezembro de 2019.

Disponível em: http://.seer.fundarte.rs.gov.br/index.php/RevistadaFundarte/index> 20 de dezembro de 2019. 


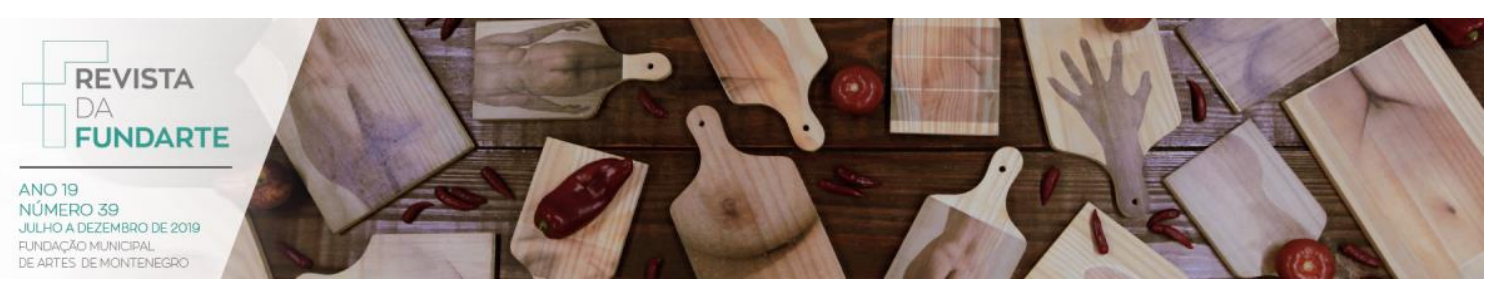

especialista e é ele quem deverá tomar as rédeas do processo educativo. (FONTERRADA, 1998, p. 22-23).

Para que esse trabalho aconteça dentro de sala de aula, conforme Ponso (2014) a interdisciplinaridade é de suma importância. Afinal, o professor regente da turma, que pode não ser músico, nem professor de educação musical, necessitará de um projeto de trabalho bem elaborado e um aprofundamento das teorias, juntamente com o profissional de música, que poderá assumir seu papel quando as ações necessitarem de um especialista. Pensar uma atividade sob a ótica interdisciplinar requer um exercício constante de troca entre os professores, ou seja, não é apenas questão de conteúdo, deve-se considerar a criança e suas potencialidades. É importante que seja um trabalho criativo, motivando e planejando as possibilidades de aprendizado (JEANDOT, 1990).

Ferreira explica que trabalhar com a música de forma interdisciplinar permite 0 desenvolvimento da linguagem sonora e uma melhor afinidade com disciplinas em que utilizamos a linguagem verbal, sendo que um dos elementos também é a sonoridade. O ensino da escola sendo interdisciplinar, utilizando a música como elemento didático e tratado com prioridade nos planejamentos diários, fará uma mudança na maneira como os conteúdos são trabalhados e a forma como os alunos reagirão diante desse processo (FERREIRA, 2002).

Lima e Stencil (2010) tratam do repertório trabalhado em sala de aula, considerando-se sua escolha, ampliação e desenvolvimento. Conforme as autoras deve-se considerar não somente as variadas maneiras de nos relacionarmos com a música no contexto interdisciplinar, mas também "associarmos a ela os diversos contextos culturais, por meio de um repertório que tenha significado e que parta dos alunos, valorizando a vivência das crianças, trazendo benefícios a outras áreas do currículo" (LIMA; STENCEL, 2010, p. 90).

A interdisciplinaridade permitirá que seja estabelecido um diálogo entre as áreas do conhecimento e a prática docente que pode refletir isso, trazendo uma

MOREIRA, Paloma Bastos; WOLFFENBÜTTEL, Cristina Rolim. Investigando sobre música e alfabetização na escola. Revista da FUNDARTE. Montenegro, p. 24-47, ano 19, ํㅡ 39, julho/dezembro de 2019.

Disponível em: http://.seer.fundarte.rs.gov.br/index.php/RevistadaFundarte/index $>20$ de dezembro de 2019. 


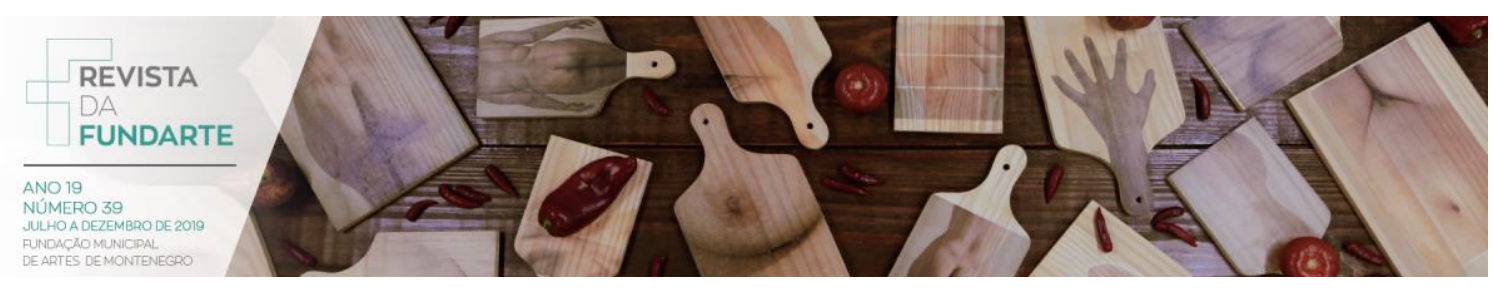

profunda imersão nos conceitos da escola, currículo ou didática. Entende-se, em sintonia com Fazenda (2008), que as:

\begin{abstract}
ligações de interdependência, de convergência e de complementaridade entre as diferentes matérias escolares que formam o percurso de uma ordem de ensino ministrado, o ensino primário, por exemplo, a fim de permitir que surja do currículo escolar - ou de lhe fornecer - uma estrutura interdisciplinar segundo as orientações integradoras. (FAZENDA, 2008, p. $57)$.
\end{abstract}

Visualizar nos outros, além de em si mesmos, além dos conteúdos propostos, das atividades, acreditar que cada aluno pode fazer parte desse processo, já que a didática utilizada contribui com a aprendizagem e o desenvolvimento de habilidades, tanto do aluno quanto do professor.

Considerando-se o que foi tratado anteriormente, questiona-se: Como a música é utilizada no planejamento escolar? Qual a frequência do uso da música neste planejamento? Qual o contato que as professoras alfabetizadoras tiveram com a Educação Musical em sua formação inicial? Qual o conhecimento e 0 entendimento das professoras em relação à Lei no 11.769/2008, que dispõe sobre a obrigatoriedade do ensino da música na Educação Básica? Considerando-se esses questionamentos, esta pesquisa objetivou analisar como a música é utilizada interdisciplinarmente no processo de alfabetização nos Anos Iniciais nas escolas municipais da cidade de São Luiz Gonzaga. Compreende-se que, com estes questionamentos e objetivo, seja possível alargar os passos na questão didática e repensar a maneira como se ensina é o começo de um processo de mudanças que podem ocorrer dentro da sala de aula, na escola e na comunidade.

Passa-se, a seguir, a apresentar a metodologia empreendida para a realização da presente investigação.

\title{
Metodologia
}

A pesquisa fundamentou-se na abordagem qualitativa, exploratória e participante, utilizando como técnicas para a coleta dos dados a aplicação de

MOREIRA, Paloma Bastos; WOLFFENBÜTTEL, Cristina Rolim. Investigando sobre música e alfabetização na escola. Revista da FUNDARTE. Montenegro, p. 24-47, ano 19, ํㅡ 39, julho/dezembro de 2019.

Disponível em: http://.seer.fundarte.rs.gov.br/index.php/RevistadaFundarte/index $>20$ de dezembro de 2019. 


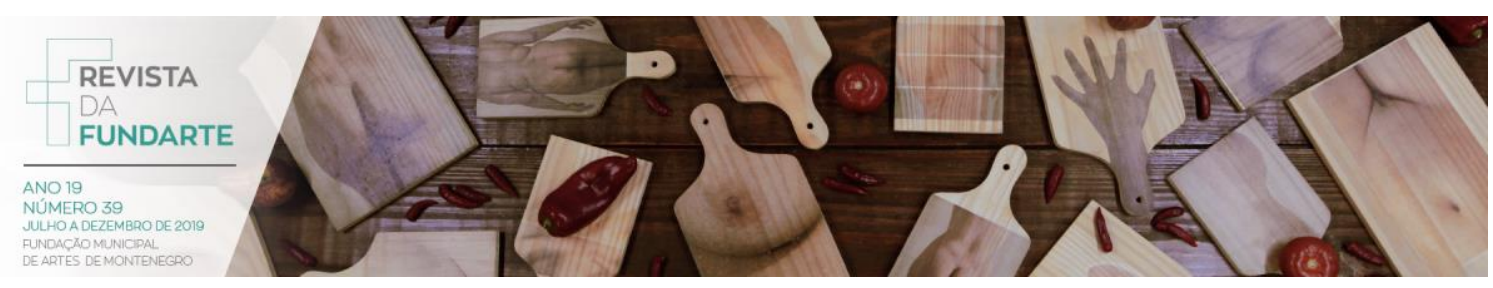

questionários autoadministrados com professoras dos Anos Iniciais do Ensino Fundamental de escolas municipais de São Luiz Gonzaga, bem como observações de suas práticas. Além dessas formas de coleta dos dados, foram realizados contatos com as coordenações pedagógicas de cada escola cujas professoras foram investigadas. Propôs-se, assim, uma investigação de cunho exploratório e descritivo com estudo bibliográfico. Adicionalmente, considerando-se a premissa da necessidade da ampliação da formação continuada em música junto às professoras, foi proposto um projeto de extensão na cidade, com vistas a implementar atividades musicais nas escolas.

A rede municipal é composta por 11 escolas, distribuídas nas zonas rural e urbana. Destas, oito escolas da zona urbana compuseram o universo de pesquisa devido à dificuldade de deslocamento para as escolas que se encontram na zona rural. Das oito escolas que receberam o questionário, somente uma não o respondeu dentro do tempo previsto, e sete escolas devolveram os questionários respondidos. Os questionários estruturados com perguntas abertas e fechadas continham perguntas sobre a formação das professoras, o tempo que lecionavam na escola, questões sobre a contribuição da música em sala de aula e o conhecimento das mesmas sobre a obrigatoriedade da lei que institui a música no currículo escolar.

A coleta e a análise de dados ocorreram por meio do estudo exploratório específico com o propósito de produzir categorias conceituais (MARCONI; LAKATOS, 2003). A organização de categorias conceituais ou descritivas, conforme Gil (2002):

Consiste na organização dos dados de forma que o pesquisador consiga tomar decisões e tirar conclusões a partir deles. Isso requer a construção de um conjunto de categorias descritivas, que podem ser fundamentadas no referencial teórico da pesquisa. (GIL, 2002, p. 134).

Assim, conforme Gil (2002), as categorias são consideradas o próprio conteúdo do estudo, sendo a análise não apenas explícita, mas também

MOREIRA, Paloma Bastos; WOLFFENBÜTTEL, Cristina Rolim. Investigando sobre música e alfabetização na escola. Revista da FUNDARTE. Montenegro, p. 24-47, ano 19, ํㅡ 39 , julho/dezembro de 2019.

Disponível em: http://.seer.fundarte.rs.gov.br/index.php/RevistadaFundarte/index $>20$ de dezembro de 2019. 


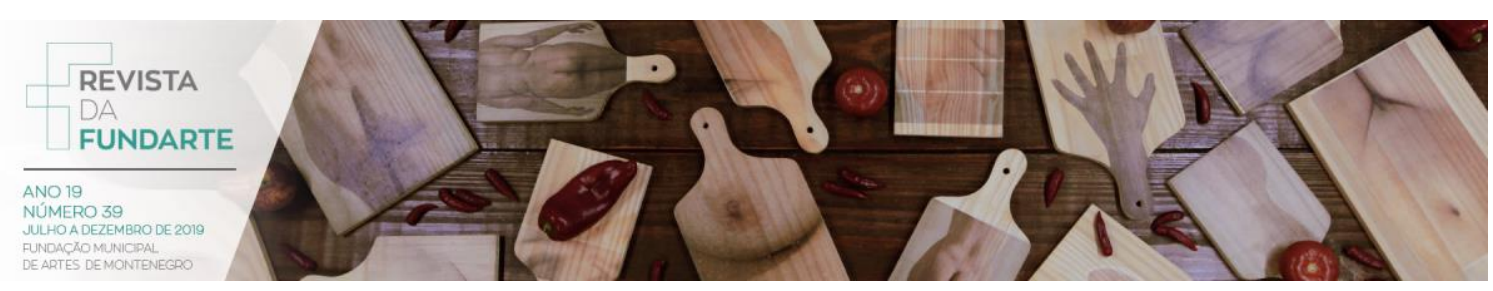

considerando aspectos implícitos, que se tornam fundamentais para obter conclusões.

O levantamento dos dados foi composto pela pesquisa bibliográfica, com vistas à revisão de literatura da área da educação musical no que diz respeito à educação musical e unidocência.

Por meio da análise dos dados, foi possível refletir sobre a importância da educação musical na alfabetização, da relação entre a música e a alfabetização e os benefícios para a aprendizagem da criança. O questionário autoadministrado permitiu o levantamento de dados para ressaltar a necessidade de formação continuada em educação musical de professores unidocentes. Esta constatação resultou na elaboração e realização de um curso de formação continuada para professores da cidade.

\section{Resultados e Análises dos Dados}

Após todos os procedimentos de coleta e análise dos dados, resultaram três categorias de análise, quais sejam, música e suas contribuições na interpretação, contribuição da música como atividade lúdica, e música como contribuição no currículo escolar.

\section{Música e suas Contribuições na Interpretação}

Interpretando e analisando os depoimentos das professoras, no que se refere à música e suas contribuições na interpretação, foram destacadas duas falas importantes, em que as professoras enfatizam a forma como utilizam a música. Conforme o depoimento da Professora A, geralmente ela utiliza a música "3 a 4 vezes no trimestre para o canto, interpretação da letra, produção de texto, preparação de auditório e dramatização". Além disso, frequentemente ela utiliza "texto, audição, escrita, interpretação, gramática, dentre outras atividades".

Os Parâmetros Curriculares Nacionais preveem a interpretação, a improvisação e a realização de composições para o ensino da música. Como julho/dezembro de 2019.

Disponível em: http://.seer.fundarte.rs.gov.br/index.php/RevistadaFundarte/index $>20$ de dezembro de 2019. 


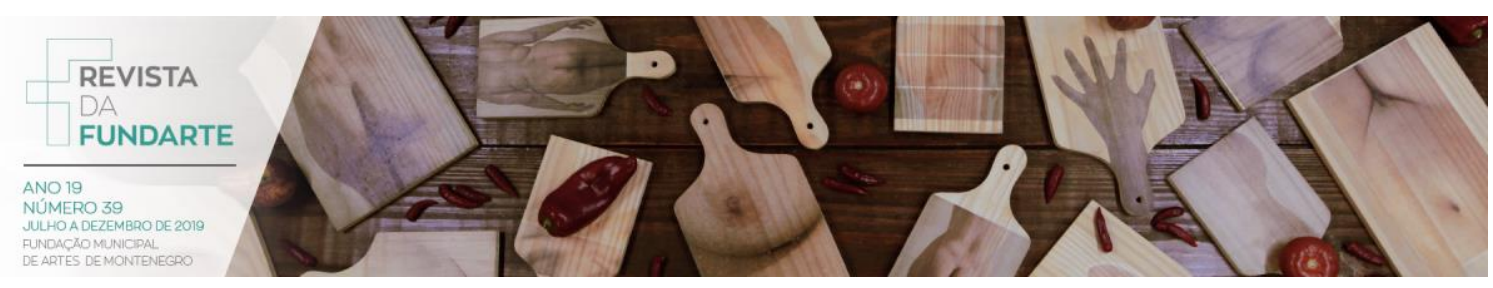

elementos de comunicação e expressão, dentre seus objetivos, podem ser destacadas atividades de interpretação de músicas existentes, vivenciando um processo de expressão individual ou grupal, dentro e fora da escola (BRASIL, 1997c).

Ao analisar este objetivo, é possível compreender que a interpretação da letra de uma canção ou a produção de escritas relativas à música faz parte desse processo. Conforme os Parâmetros Curriculares Nacionais (BRASIL, 1997c):

O momento da interpretação é aquele em que o projeto ou a partitura se tornam música viva. As interpretações são importantes na aprendizagem, pois tanto o contato direto com elas quanto a sua utilização como modelo são maneiras de o aluno construir conhecimento em música. Além disso, as interpretações estabelecem os contextos onde os elementos da linguagem musical ganham significado. (BRASIL, 1997c, p. 48).

Compreendendo os demais elementos, vemos as composições musicais que devem ocorrer por meio de projetos, escolhendo sons, linguagens ou materiais sonoros que os rodeiam, diferenciando os parâmetros altura, duração, intensidade e timbre e, assim, produzindo música. A improvisação é um elemento atrelado à composição e à interpretação que deve acontecer de forma bem estruturada para que a liberdade de criação possa ser alcançada pela consciência dos limites (BRASIL, 1997c).

Como a música é uma linguagem, segundo Deckert (2012), Saussure trouxe conceitos da linguística verbal para o sistema de linguagem musical, sendo esta também constituída de signos, possuindo significante e significados próprios que diferem e devem ser estudados dependendo da cultura em que está inserida. Segundo Silva (2013), a música pode ser considerada como atividade de interpretação textual, já que possui características que podem ser interpretadas e possuem sentido. Conforme Costa (2002), a canção é um gênero hibrido, composto de dois tipos de linguagens, a verbal e a musical. Para a utilização da música como interpretação da letra, França (2010) esclarece e sugere:

MOREIRA, Paloma Bastos; WOLFFENBÜTTEL, Cristina Rolim. Investigando sobre música e alfabetização na escola. Revista da FUNDARTE. Montenegro, p. 24-47, ano 19, no 39, julho/dezembro de 2019.

Disponível em: http://.seer.fundarte.rs.gov.br/index.php/RevistadaFundarte/index> 20 de dezembro de 2019. 


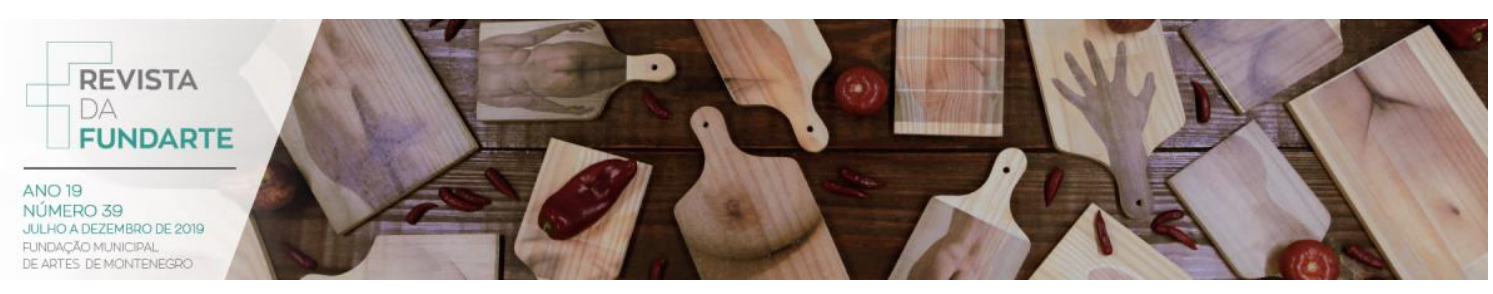

Do ponto de vista musical, a ideia é desconstruir e reconstruir, transgredir e transformar a forma. Da perspectiva do letramento, é dominar a escrita, e não ser domado por ela. Brincar com as letras, palavras e onomatopeias, variando sua intensidade, altura e direção, combinando-as, cruzando-as e retrogradando-as, pode conferir ao processo de letramento uma dimensão lúdica e criativa. (FRANÇA, 2010, p. 18).

Brincar com as letras das canções, interpretá-las, formar novas palavras, enfim, atividades como essas possibilitam aos alunos serem ativos no aprendizado, potencializando a educação musical e a alfabetização.

\section{Contribuição da Música como Atividade Lúdica}

A educação musical pode trazer novas perspectivas para o ensino escolar, pode-se criar um trabalho pedagógico musical diferenciado que oportunize às crianças momentos que possam utilizar a música como jogo, para percepção, apreciação, improvisação, composição, construção de instrumentos musicais próprios, dentre outras atividades.

Uma das professoras investigadas nesta pesquisa enfatizou o trabalho lúdico e a contribuição da música nesse processo. Conforme a Professora $\mathrm{C}$, poucas vezes ela utiliza a música. Mas, quando a utiliza, faz uso de "brincadeiras, gestos, mímicas, para descontrair e alegrar". A professora $D$ explicou que utiliza a música "nas brincadeiras como forma de diversão e, às vezes, para introdução de conteúdo; são cantigas de rodas, músicas infantis, etc.".

Brito (2003, p. 46) explica que "um trabalho pedagógico-musical deve se realizar em contextos educativos que entendam a música como processo de construção, que envolve perceber, sentir, experimentar, imitar, criar e refletir". As contribuições da música nos anos iniciais podem se tornar riquíssimas se adaptadas em sala de aula na alfabetização, iniciando pelos processos de exploração musical. Conforme França e Swanwick (2002):

Nos estágios iniciais, o objetivo deve ser brincar, explorar, descobrir possibilidades expressivas dos sons e sua organização, e não, dominar técnicas complexas de composição, o que poderia resultar em um esvaziamento do seu potencial educativo. Nas aulas, muitas oportunidades

MOREIRA, Paloma Bastos; WOLFFENBÜTTEL, Cristina Rolim. Investigando sobre música e alfabetização na escola. Revista da FUNDARTE. Montenegro, p. 24-47, ano 19, ํㅡ 39, julho/dezembro de 2019.

Disponível em: http://.seer.fundarte.rs.gov.br/index.php/RevistadaFundarte/index> 20 de dezembro de 2019. 


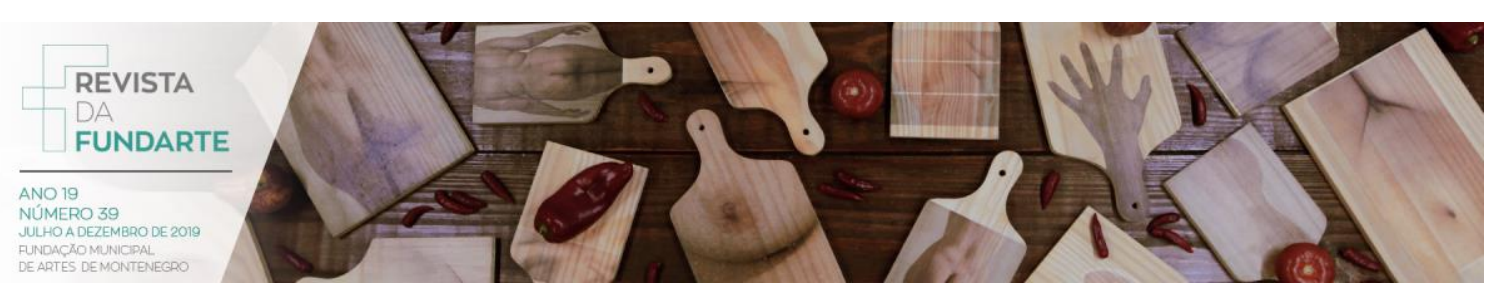

para compor podem surgir a partir da experimentação que demanda ouvir, selecionar, rejeitar e controlar o material sonoro. (FRANÇA; SWANWICK, 2002, p. 10).

As brincadeiras, os gestos, as mímicas, sendo utilizadas musicalmente com propósito e planejamento, podem resultar nessa experimentação que é necessária para aprender sobre música, distinguir sons, apreciar os sons a sua volta, desenvolver habilidades corporais, pois é necessário trabalhar o corpo para compreender conceitos de ritmo e, principalmente, os parâmetros do som como altura, duração, intensidade e timbre.

Delalande (2013) relaciona os jogos de Piaget com as fases de desenvolvimento do aprendizado musical, incluindo a exploração sonora, a criação e a performance. $\mathrm{O}$ autor elenca $\mathrm{O}$ jogo sensório-motor, que está vinculado à exploração do som e do gesto, o jogo simbólico, que se vincula ao valor expressivo e à significação mesma do discurso musical, e o jogo com regras, vinculado à organização e à estruturação da linguagem musical.

Essa proposta está vinculada culturalmente à evolução da música ao longo dos tempos, apresentando a função lúdica na sociedade. Essas dimensões estão presentes na escola, principalmente através de brincadeiras e jogos, na educação infantil e primeiros anos. Conforme Oliveira (2002), "por meio da brincadeira, a criança pequena exercita capacidades nascentes, como as de representar o mundo e de distinguir entre pessoas, possibilitadas especialmente pelos jogos de faz-deconta e os de alternância respectivamente". Além disso:

Ao brincar, a criança passa a compreender as características dos objetos, seu funcionamento, os elementos da natureza e os acontecimentos sociais. Ao mesmo tempo, ao tomar o papel do outro na brincadeira, começa a perceber as diferenças perspectivas de uma situação, o que lhe facilita a elaboração do diálogo interior característicos de seu pensamento verbal. (OLIVEIRA, 2002, p. 160).

As cantigas de roda também são importantes para a educação musical. Por meio dessas cantigas as crianças entram em contato com a música, algumas conhecem cantigas aprendidas em casa e outras, quando inseridas na Educação

MOREIRA, Paloma Bastos; WOLFFENBÜTTEL, Cristina Rolim. Investigando sobre música e alfabetização na escola. Revista da FUNDARTE. Montenegro, p. 24-47, ano 19, ํㅡ 39 , julho/dezembro de 2019.

Disponível em: http://.seer.fundarte.rs.gov.br/index.php/RevistadaFundarte/index $>20$ de dezembro de 2019. 


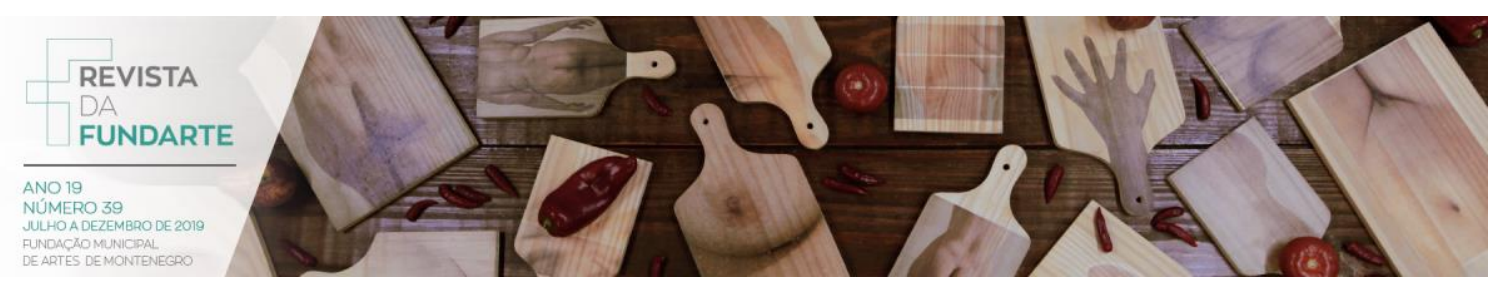

Infantil. São raros os casos de crianças que não conheçam nenhuma cantiga e, nos anos iniciais, pode-se continuar trabalhando, tanto as cantigas de roda, quanto as parlendas, levando em consideração as que possuem importância e significado para as crianças e a comunidade onde vivem (BRITO, 2003).

Atividades corporais musicais, como os gestos e mímicas, também são muito importantes no processo pedagógico-musical. Dalcroze, por exemplo, enfatizou o uso do corpo com vistas ao ensino de música.

A rítmica criada por Jacques-Dalcroze pretendia desvencilhar o aluno de uma prática mecânica no aprendizado da música, normalmente apoiado na análise, na leitura e na escrita sem a participação do corpo, que ele considera fundamental para a sensibilização da consciência rítmica. (MARIANI, 2011, p. 31).

Tanto os sentidos, quanto os sentimentos e a coordenação motora são desenvolvidos por meio da música em atividades que utilizem o corpo para a criação e descobertas. Dalcroze desejava que, além de ser utilizada a rítmica na educação musical, pudesse ser adaptada a realidade social e cultural do aluno (MARIANI, 2011).

Todas as atividades relacionadas não formam um determinado fim, pelo contrário, podem ser o início de mudanças que poderão acontecer quando houver comprometimento do professor em aprender e ensinar, conhecer seus alunos e suas necessidades em que didática poderá se adaptar melhor na alfabetização. Cada criança possui conhecimentos musicais, uma bagagem musical que pode aflorar através de uma adequada educação musical.

\section{Música como Contribuição no Currículo Escolar}

A música como parte do currículo escolar foi elencada para a discussão, pois grande parte das professoras acredita que ela traz muitas contribuições para o currículo escolar. Conforme a Professora E, a música traz "alegria, ânimo, reforça um conteúdo e estimula o aluno a aprender mais". Além desse depoimento, a

MOREIRA, Paloma Bastos; WOLFFENBÜTTEL, Cristina Rolim. Investigando sobre música e alfabetização na escola. Revista da FUNDARTE. Montenegro, p. 24-47, ano 19, ํㅡ 39, julho/dezembro de 2019.

Disponível em: http://.seer.fundarte.rs.gov.br/index.php/RevistadaFundarte/index $>20$ de dezembro de 2019. 


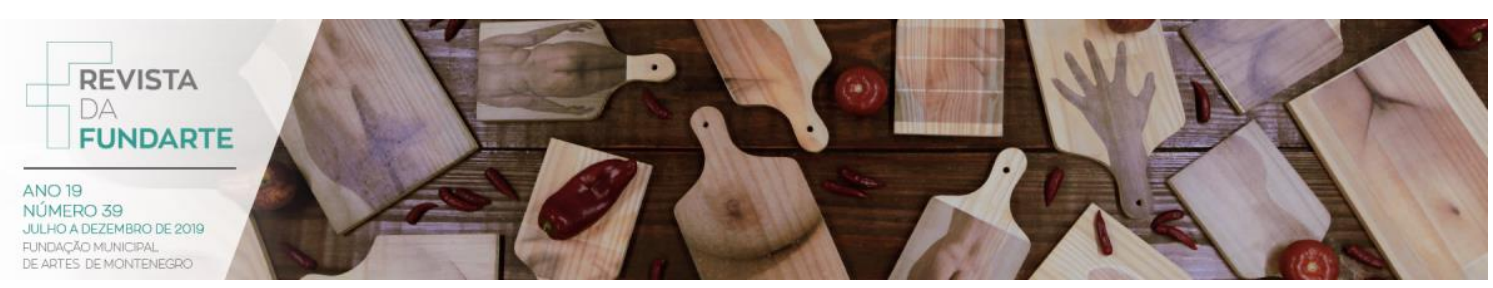

Professora F apontou que, inclusive, a música "deve fazer parte do currículo escolar".

Para contribuir com esta análise, vale entender o conceito de currículo como "a ligação entre a cultura e a sociedade exterior à escola e à educação; entre o conhecimento e cultura herdados e a aprendizagem dos alunos; entre a teoria (ideias, suposições e aspirações) e a prática possível, dadas determinadas condições" (SACRISTÁN, 1999, p. 61).

As discussões sobre o currículo, segundo Domingues (2013), deixaram há algum tempo de ter como base o planejamento, a organização, as metas e os objetivos. A teoria crítica do currículo passa a questionar, também, o lugar das disciplinas do currículo, sendo essas pesquisas iluminadas por Henry Giroux, que também coloca o papel do professor na escolha do currículo (DOMINGUES, 2013).

O currículo escolar reflete, ou deveria refletir, a escola e sua função social, e a sociedade que vive em constantes transformações. Relacionando-o à educação, o currículo passou por mudanças ao longo do tempo; vemos, hoje, alunos ativos que assimilam e buscam maneiras no seu meio para aprender, não são mais agentes passivos que só aprendem o que o professor transmite em sala de aula.

Em 1997, o Ministério da Educação e a Secretaria de Educação Fundamental disponibilizaram os Parâmetros Curriculares Nacionais, compostos por 10 volumes caracterizados como "referenciais para a renovação e reelaboração da proposta curricular" (BRASIL, 1997a, p. 9), buscando melhorar a educação e auxiliar o professor no seu papel de formação, objetivando "contribuir, de forma relevante, para que profundas e imprescindíveis transformações [...] se façam no panorama educacional brasileiro" (BRASIL, 1997a, p. 9).

Adiante lemos que:

Não configuram, portanto, um modelo curricular homogêneo e impositivo, que se sobreporia à competência político-executiva dos Estados e Municípios, à diversidade sociocultural das diferentes regiões do País ou à autonomia de professores e equipes pedagógicas. (BRASIL, 1997a, p. 13).

MOREIRA, Paloma Bastos; WOLFFENBÜTTEL, Cristina Rolim. Investigando sobre música e alfabetização na escola. Revista da FUNDARTE. Montenegro, p. 24-47, ano 19, ํㅡ 39 , julho/dezembro de 2019.

Disponível em: http://.seer.fundarte.rs.gov.br/index.php/RevistadaFundarte/index $>20$ de dezembro de 2019. 


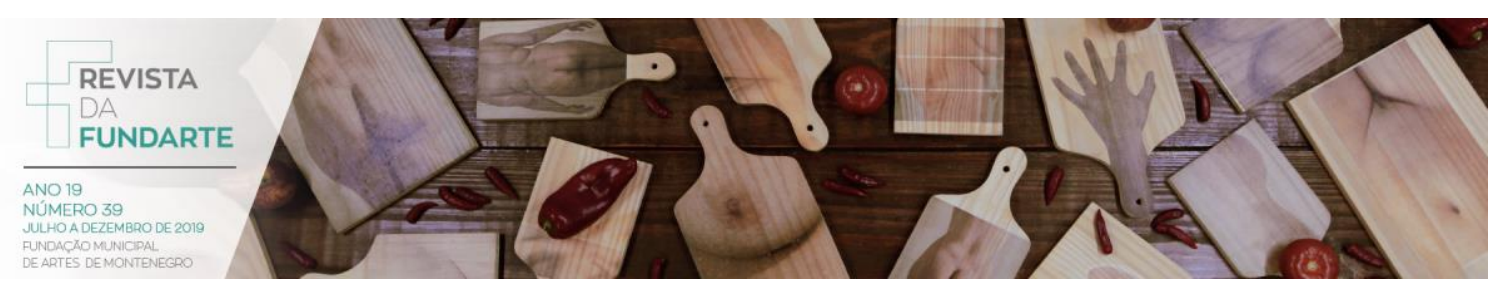

Diversidade sociocultural e autonomia do professor são palavras importantes, levando-se em consideração a cultura de cada região, estado, cidade, bairro e possuindo autonomia para incluir no currículo tais observações e fatos que fazem parte diariamente da vida dos alunos e que, muitas vezes, é necessário discutir e refletir em sala de aula.

Ainda para caracterizar os documentos propostos, estes apresentam "diferentes elementos curriculares tais como caracterização das áreas, objetivos, organização dos conteúdos, critérios de avaliação e orientações didáticas" (BRASIL, 1997a, p. 29), deixando claro como se organiza o currículo proposto e sua divisão de elementos para compreensão dos professores. Dentre estas áreas, encontram-se as Artes, presentes no volume 6, que abrange Artes Visuais, Dança, Música e Teatro, ou seja, a Música faz parte do currículo escolar e a luta para que isso acontecesse é histórica, como dito anteriormente.

A música foi acrescentada e excluída muitas vezes do currículo. Em 2008, por meio da Lei no 11.769, tornou-se efetiva sua posição no espaço escolar, o que não significa que, realmente, ela esteja presente em sala de aula e, com certeza, são necessárias ações para que a música atinja a valorização merecida.

Ao problematizar a questão do currículo, o conteúdo para o ano letivo é proposto pela Secretaria Municipal de Educação que, por sua vez, está subordinada ao Sistema Nacional de Educação e, assim, o professor deve realizar seus planejamentos escolares, em alguns casos sem meios de expor propostas, o que resulta na reprodução apenas do que é exigido.

A música não só deve fazer parte do currículo escolar, como é parte do currículo, já que possuímos os Parâmetros Curriculares de Educação e a lei prevê a obrigatoriedade do ensino da música em sala de aula, mas o que está impedindo essa efetivação pode ser a falta de suporte metodológico e de formação dos professores, ou seja, retornamos a nossa discussão ao ponto que reforça a pesquisa.

MOREIRA, Paloma Bastos; WOLFFENBÜTTEL, Cristina Rolim. Investigando sobre música e alfabetização na escola. Revista da FUNDARTE. Montenegro, p. 24-47, ano 19, ํo 39, julho/dezembro de 2019.

Disponível em: http://.seer.fundarte.rs.gov.br/index.php/RevistadaFundarte/index $>20$ de dezembro de 2019. 


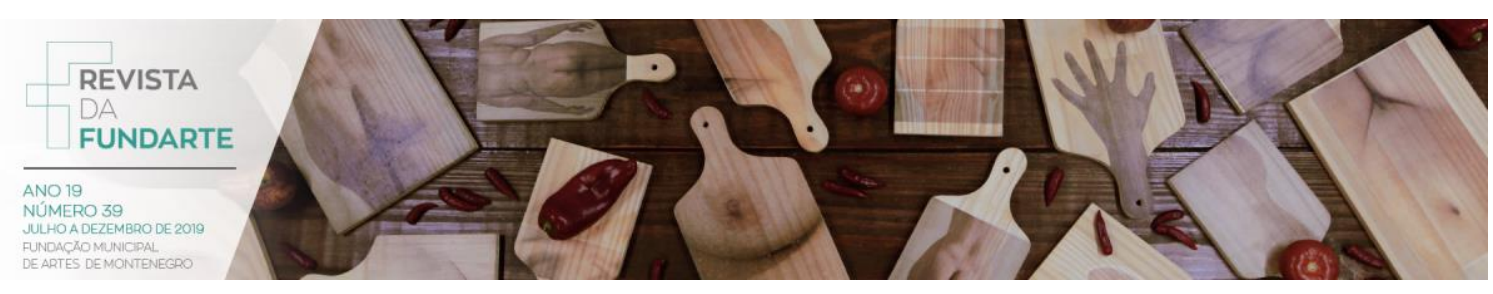

\section{Considerações Finais}

Esta investigação analisou a utilização da música na alfabetização escolar, objetivando analisar como a música é utilizada interdisciplinarmente no processo de alfabetização nos Anos Iniciais, nas escolas municipais da cidade de São Luiz Gonzaga. Teve como desenho metodológico a abordagem qualitativa exploratória, utilizando como técnicas para a coleta dos dados questionários autoadministrados, os quais foram aplicados junto às professoras dos Anos Iniciais do Ensino Fundamental. As observações complementaram a análise dos dados, juntamente com os contatos com as coordenações pedagógicas.

Os questionamentos que nortearam a investigação foram: Como a música é utilizada no planejamento escolar? Qual a frequência do uso da música neste planejamento? Qual o contato que as professoras alfabetizadoras tiveram com a Educação Musical em sua formação inicial? Qual o conhecimento e o entendimento das professoras em relação à Lei $n$ ํ 11.769/2008, que dispõe sobre a obrigatoriedade do ensino da música na Educação Básica? Passa-se, portanto, a respondê-los.

Quanto à questão relacionada à utilização da música no planejamento escolar, observou-se, a partir das entrevistas realizadas e das observações, que as professoras utilizam a música e as atividades musicais em diversos momentos na sala de aula. Na maioria das vezes as atividades pedagógico-musicais são inseridas com vistas à potencialização de algum objetivo relacionado ao letramento ou à alfabetização. Este não se constituiu em um problema, pois a educação musical pode se apresentar de diversos modos. No entanto, a falta de professores de música, ainda na atualidade, apesar da legislação existente e vigente, não permite que a educação musical na escola possa se apresentar com sua abrangência.

Em se tratando da frequência com a qual as professoras alfabetizadoras utilizam a música em seus planejamentos, percebeu-se que as atividades musicais encontram-se frequentemente nos planejamentos, o que aponta a importância que Ihes é destinada no trabalho do cotidiano escolar.

MOREIRA, Paloma Bastos; WOLFFENBÜTTEL, Cristina Rolim. Investigando sobre música e alfabetização na escola. Revista da FUNDARTE. Montenegro, p. 24-47, ano 19, ํㅡ 39, julho/dezembro de 2019.

Disponível em: http://.seer.fundarte.rs.gov.br/index.php/RevistadaFundarte/index $>20$ de dezembro de 2019. 


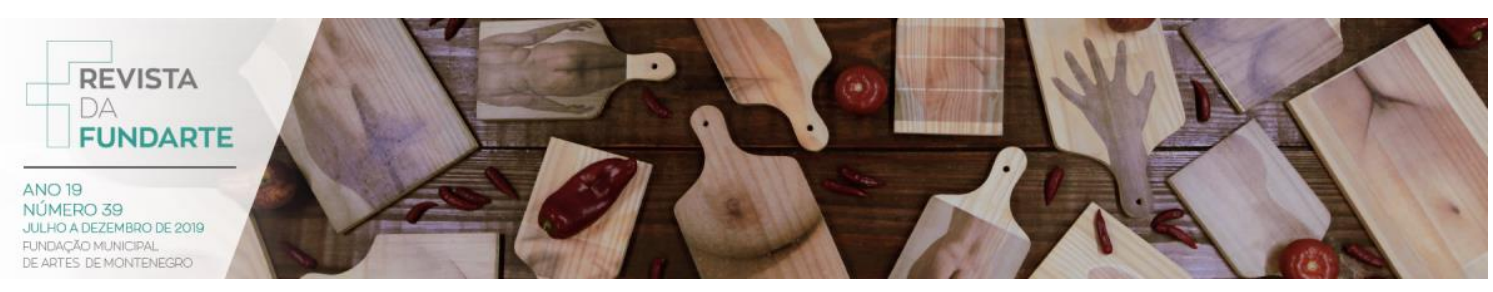

Outro questionamento que norteou esta pesquisa relacionou-se ao contato que as professoras alfabetizadoras tiveram com a Educação Musical em sua formação inicial, observou-se que o mesmo não pareceu do modo suficiente e necessário para fundamentar o trabalho pedagógico-musical em sala de aula das mesmas. Em meio aos depoimentos observou-se que o tempo que foi destinado ao ensino na formação inicial foi pequeno em relação ao necessário, ou mesmo não ocorreu. Esse aspecto aponta para a necessidade de uma ação mais efetiva dos sistemas de ensino, no caso desta pesquisa, as secretarias municipais e estaduais de educação. Em vista disso, na ocasião da pesquisa foi realizada uma ação extensiva da Universidade Estadual do Rio Grande do Sul, à qual esta pesquisa esteve atrelada. Essa formação constituiu-se num curso com cerca de 50 horas, no qual foi oferecida a formação em educação musical, em alfabetização e atividades lúdicas. Entende-se que este seja um aspecto a ser superado quanto à formação inicial de professoras unidocentes, bem como das alfabetizadoras.

Perguntou-se, também, às professoras o que conheciam e entendiam sobre a Lei no 11.769/2008, que dispõe sobre a obrigatoriedade do ensino da música na Educação Básica. Apesar de esta lei já ter cerca de dez anos de existência, e muitas ações em prol da educação musical terem sido realizadas ao longo dos anos, por diversas instituições, ainda se percebe que o conhecimento da legislação é pouco. Mas, essa não é uma característica afeta, apenas, às professoras investigadas. De um modo geral, tanto na educação, quanto em outras áreas do conhecimento, observa-se que o conhecimento em relação às leis é, ainda, insipiente. Este aspecto parece ser, ainda, um dos pontos a serem trabalhados, tanto na formação inicial, quanto continuada.

Ao finalizar este artigo, resultado de uma investigação juntas às professoras alfabetizadoras em São Luiz Gonzaga, entende-se a importância destas profissionais no processo de escolarização das crianças e, do mesmo modo, o quanto as mesmas podem contribuir com o desenvolvimento da educação musical escolar. Não se faz, aqui, uma apologia à extinção de professores de música das escolas. Ao contrário, cada vez mais se percebe que o trabalho pedagógico-musical

MOREIRA, Paloma Bastos; WOLFFENBÜTTEL, Cristina Rolim. Investigando sobre música e alfabetização na escola. Revista da FUNDARTE. Montenegro, p. 24-47, ano 19, ํㅡ 39, julho/dezembro de 2019.

Disponível em: http://.seer.fundarte.rs.gov.br/index.php/RevistadaFundarte/index $>20$ de dezembro de 2019. 


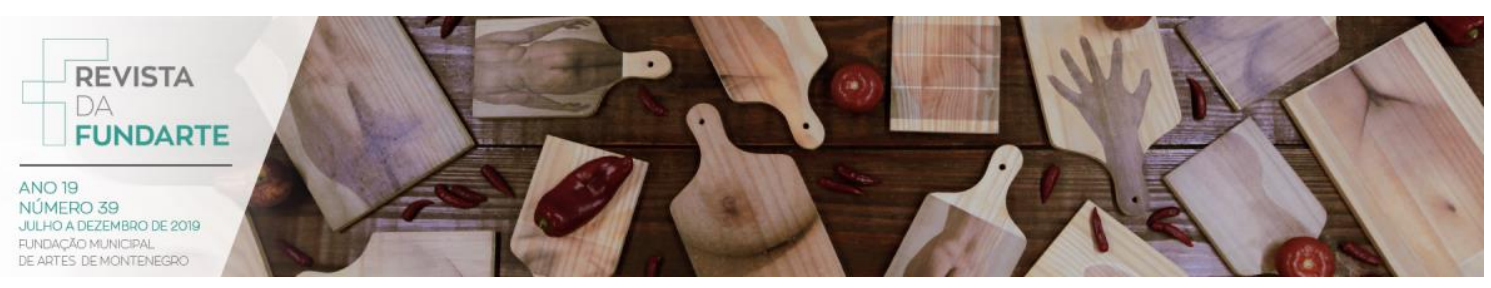

desenvolvido por professores de música e professores unidocentes é diferente. Ambos são importantes, diferentes e complementares. Cabe, portanto, um cuidado maior quanto à elaboração das propostas pedagógicas dos cursos de Pedagogia, a fim de garantir um bom ensino de música na formação inicial. Assim, entende-se que professores de música e professores unidocentes possam trabalhar juntos, em prol da educação musical e de uma educação mais humana e integral.

\section{Referências:}

BELLOCHIO, Cláudia Ribeiro; WEBER, Vanessa; SOUZA, Zelmielen Adornes de. Música e unidocência: pensando a formação e as práticas de professores de referência. Rev. FAEEBA - Ed. e Contemp., Salvador, v. 26, n. 48, p. 205-221, jan./abr. 2017.

BRASIL. Lei 11.769, de 18 de agosto de 2008. Altera a Lei no 9.394, de 20 de dezembro de 1996, Lei de Diretrizes e Bases da Educação, para dispor sobre a obrigatoriedade do ensino da música na educação básica. Disponível em: <http://www.planalto.gov.br/ccivil_03/_ato2007-2010/2008/lei//11769.htm>. Acesso em: 15 mar. 2018.

Lei 4.624, de 1961. Estabelece as diretrizes e bases da educação nacional. Brasília, 1996. Disponível em: < http://www2.camara.leg.br/legin/fed/lei/19601969/lei4024-20-dezembro-1961-353722-publicacaooriginal-1-pl.html>. Acesso em: 05 set. 2018.

LDB. Lei 9394/96 - Lei de Diretrizes e Bases da Educação Nacional. Disponível em < www.planalto.gov.br >. Acesso em: 05 set. 2018.

Secretaria de Educação Fundamental. Parâmetros curriculares nacionais: Introdução aos parâmetros curriculares nacionais / Secretaria de Educação Fundamental. - Brasília: MEC/SEF, 1997a.

Secretaria de Educação Fundamental. Parâmetros curriculares nacionais: língua portuguesa. Vol.2. Brasília: MEC/ SEF, 1997b.

Secretaria de Educação Fundamental. Parâmetros curriculares nacionais: arte. Vol.6. Brasília: MEC/ SEF, 1997c.

BRITO, Teca Alencar. Música na educação infantil: propostas para a formação integral da criança. São Paulo: Peirópolis, 2003.

MOREIRA, Paloma Bastos; WOLFFENBÜTTEL, Cristina Rolim. Investigando sobre música e alfabetização na escola. Revista da FUNDARTE. Montenegro, p. 24-47, ano 19, ํㅡ 39, julho/dezembro de 2019.

Disponível em: http://.seer.fundarte.rs.gov.br/index.php/RevistadaFundarte/index $>20$ de dezembro de 2019. 


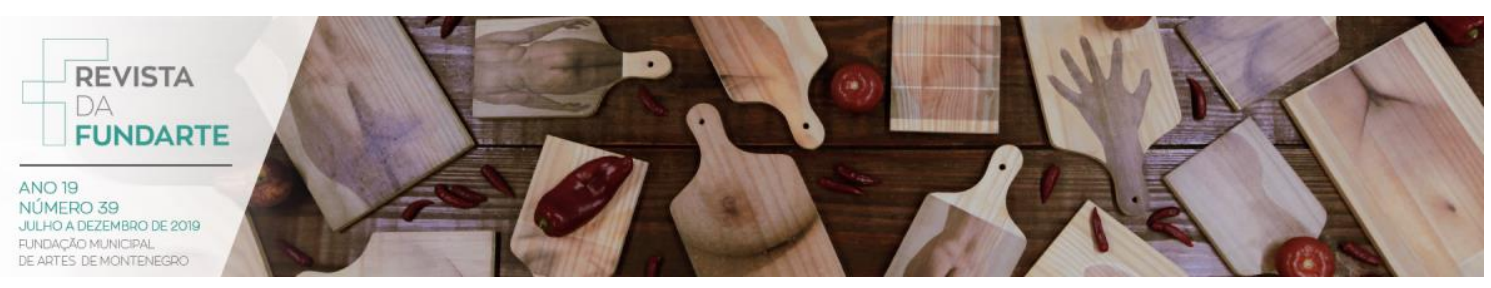

COSTA, Nelson Barros da. As letras e a letra: o gênero canção na mídia literária. In: DIONISIO, Angela Paiva; MACHADO, Anna Rachel; BEZERRA, Maria Auxiliadora (Org.). Gêneros textuais e ensino. 5를 ed. Rio de Janeiro: Lucerna, 2007. p. 107-121.

DECKERT, Marta. Educação musical: da teoria à pratica na sala de aula. São Paulo: Moderna, 2012.

DELALANDE, François. Las conductas musicales. Santander: Editorial de la Universidad de Cantabria, 2013.

DEMO, Pedro. Participação é conquista: noções de política social e participativa. $4^{a}$ ed. São Paulo: Cortez, 1999.

DOMINGUES, Glauber Resende. A disciplina música no currículo escolar: questões sobre uma história (des) afinada. Revista Arte \& Ciência, Rio de Janeiro, v. 1, n. 3, p. 1-17, jan./dez. 2013.

FAZENDA, Ivani C. Arantes (Org.). Didática e interdisciplinaridade. 13. ed. Campinas, SP: Papirus, 2008.

FERREIRA, Martins. Como usar música na sala de aula. São Paulo: Contexto, 2002.

FONTERRADA, Marisa Trench de Oliveira. Linguagem verbal e linguagem musical. Cadernos de Estudo: Educação Musical, São Paulo, n. 4/5, p. 30-43, 1994.

FONTERRADA, Marisa Trench de Oliveira. Os parâmetros curriculares nacionais e a área de música. CONGRESSO NACIONAL DA FEDERAÇÃO DOS ARTEEDUCADORES DO BRASIL, 11, 1998, Brasília/DF. Arte - políticas educacionais e culturais no limiar do século XXI. Anais... Brasília: [S. n.], 1998. p. 1527.

FRANÇA, Cecilia Cavalieri. Sopa de letrinhas: notações analógicas (des)construindo a forma musical. Música na Educação Básica, Porto Alegre, v.2, n. 2, p. 9-21, set. 2010.

FRANÇA, Cecília Cavalieri; SWANWICK, Keith. Composição, apreciação e performance na educação musical: teoria, pesquisa e pratica, Em Pauta, Porto Alegre, v. 13, n. 21, p. 5-41, dez. 2002.

GIL, Antônio Carlos. Como elaborar projetos de pesquisa. 4. ed. São Paulo: Atlas, 2002.

JEANDOT, Nicole. Explorando o universo da música. São Paulo: Scipione, 1990.

MOREIRA, Paloma Bastos; WOLFFENBÜTTEL, Cristina Rolim. Investigando sobre música e alfabetização na escola. Revista da FUNDARTE. Montenegro, p. 24-47, ano 19, ํㅡ 39, julho/dezembro de 2019.

Disponível em: http://.seer.fundarte.rs.gov.br/index.php/RevistadaFundarte/index $>20$ de dezembro de 2019. 


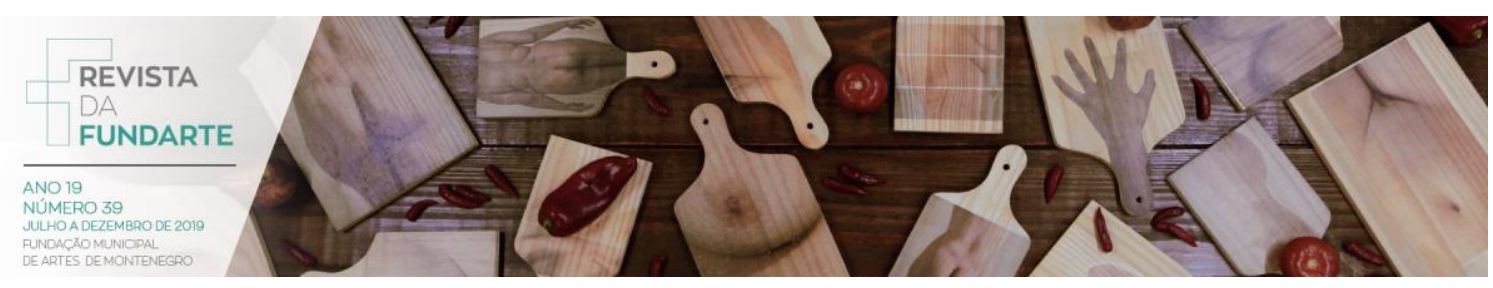

KRAEMER, Rudolf-Dieter. Dimensões e funções do conhecimento pedagógicomusical. Em Pauta, Porto Alegre, v. 11, n. 16/16, p. 48-73, abr./nov. 2000.

MARCONI, Marina de Andrade; LAKATOS, Eva Maria. Fundamentos de metodologia científica. 5. ed. São Paulo: Atlas 2003.

LIMA, Ailen Rose B. de; STENCEL, Ellen de Albuquerque B. Vivência musical no contexto escolar. Música na Educação Básica. Porto Alegre, v. 2, n. 2, p. 88- 103. Setembro de 2010.

MARIANI, Silvana. Émile Jacque- Dalcroze: A música e o movimento. In: MATEIRO, T.; ILARI, B. (Org.). Pedagogias em educação musical. Curitiba: Ibpex, 2011.

OLIVEIRA, Zilma Ramos de. Educação infantil: fundamentos e métodos. São Paulo: Cortez, 2002.

PONSO, Caroline Cao. Música em diálogo: ações interdisciplinares na educação infantil. $2^{\mathrm{a}}$ ed. Porto Alegre: Sulina, 2014.

QUEIROZ, Luis Ricardo Silva. Educação musical e cultura: singularidade e pluralidade cultural no ensino e aprendizagem da música. Revista da $A B E M$, Porto Alegre, v. 10, p. 99-107, mar. 2004.

SACRISTAN, J. Gimeno. Poderes instáveis em educação. Tradução de Beatriz Affonso Neves. Porto Alegre: Artmed, 1999.

SCHERER, Simone. A música no processo de alfabetização da criança. Porto Alegre, 2010, 39 f. Monografia (Pedagogia à Distância) - Curso de Pedagogia Modalidade à Distância. Universidade Federal do Rio Grande do Sul, 2010.

SILVA, Jéssica Carneiro. Da análise da música como gênero textual e texto multimodal ao ensino de língua portuguesa. Graduando, Feira de Santana, v. 4, n. 6/7, p. 49-60, jan./dez. 2013.

SPANAVELLO, Caroline Silveira; BELLOCHIO, Cláudia Ribeiro. Educação musical nos anos iniciais do ensino fundamental: analisando as práticas educativas de professores unidocentes. Revista da ABEM, Porto Alegre, v. 12, p. 89-98, mar. 2005.

WOLFFENBÜTTEL, Cristina Rolim; ERTEL, Daniele Isabel; SOUZA, Jusamara Vieira. Música nas escolas: uma investigação sobre a implementação nos municípios do Rio Grande do Sul. Revista Música Hodie, Goiânia, v. 16, n. 1, p. 165183, 2016.

MOREIRA, Paloma Bastos; WOLFFENBÜTTEL, Cristina Rolim. Investigando sobre música e alfabetização na escola. Revista da FUNDARTE. Montenegro, p. 24-47, ano 19, ํㅡ 39, julho/dezembro de 2019.

Disponível em: http://.seer.fundarte.rs.gov.br/index.php/RevistadaFundarte/index $>20$ de dezembro de 2019. 